\title{
Application of Activated Sludge for Urban Wastewater Treatment and Reuse for Irrigation in Kenitra, Morocco
}

\author{
Abdellah Lachheb, Youssef Azami Idrissi, Noureddine Zouhri, Sakina Belhamidi, Mohamed Taky, \\ Mahassine El Amrani, Azzddine Elmidaoui
}

Laboratory of Separation Processes, Department of Chemistry, Ibn Tofail University, Kenitra, Morocco

Email address:

Lachheb062@hotmail.com (A. Lachheb), lachheb.ae@gmail.com (A. Lachheb)

\section{To cite this article:}

Abdellah Lachheb, Youssef Azami Idrissi, Nourdine Zouhri, Sakina Belhamidi, Mohamed Taky, Mahassine El Amrani, Azzddine Elmidaoui. Application of Activated Sludge for Urban Wastewater Treatment and Reuse for Irrigation in Kenitra, Morocco. American Journal of Applied Chemistry. Vol. 4, No. 2, 2016, pp. 33-39. doi: 10.11648/j.ajac.20160402.11

Received: January 23, 2016; Accepted: February 8, 2016; Published: March 12, 2016

\begin{abstract}
The treatment domestic urban wastewater is growing nowadays, because of the rising cost of water and because of environmental pollution, and becoming an important water source for agricultural irrigation. The aim of this study was to decrease the biological oxygen demand (BOD5), chemical oxygen demand (COD) and total Suspended solids (SS) of urban wastewater the city of Kenitra by activated sludge, in first time focusing on determining the best activated sludge pilot plant operating conditions after in order to confirm the performance of the station, a long duration of the pilot purification test was conducted. The pilot operating conditions correspond in terms of mass load to a low load are: Flow $0.51 / \mathrm{h}$; Oxygenation rate $60 \% ; 100 \%$ recycling of the activated sludge; Aeration tank agitation $100 \mathrm{rev} / \mathrm{min}$. Also, a sustained performance during the trial period, during which, the station operated in low mass load, producing water with BOD5, COD and SS, which is respectively $(90.20 \%, 89.79 \%$ et $97.67 \%)$ much lower levels in Moroccan discharge standards. The final treated wastewater could be reused water for agricultural irrigation.
\end{abstract}

Keywords: Reuse, Wastewater Treatment, Activated Sludge

\section{Introduction}

The decrease in resources in natural waters brought about by drought and population growth is inciting authorities to establish and to encourage the reuse of wastewater. Thus, in several countries (United States, Australia, South Africa, Japan,) the reuse of wastewater is undergoing fast expansion with the majority of the projects having an agricultural vocation, being intended for irrigation $[1,2]$. In Morocco, although the reuse of treated wastewater is not really advanced, it is customarily used as part of the hydraulic resources of public utilities: irrigation of golf courses, public gardens and agricultural irrigation.

In addition to this, population's growth and the excessive exploitation of water resources lead to a significant increase in the volume of wastewater discharges. Thus, urban centers are constantly confronted with liquid sanitation problems and wastewater discharges in the receiving backgrounds (Valley, lakes, sea...) [3].
Unfortunately the situation in Kenitra (North West of Morocco) where domestic urban wastewater is drained through emissaries and discharged directly into the Valley Sebou. It inevitably results in a serious pollution of the latter. The consequences are regionally significant.

In a situation which necessitates an augmentation in water needs, the orientation towards new resources is increasingly becoming necessary. The reuse of treated wastewater is the first and main alternative of conventional resources, they represent a significant potential of about 500millions of $\mathrm{m} 3$ in Morocco, over 700 ha are irrigated with wastewater near major urban centers where we practice market gardening, cereal... [3, 4]. As a consequence of water shortage, the treated urban wastewater, commonly discharged to the sewer in the past, is nowadays being the reuse of treated wastewater in agriculture.

The study presented here is focused on the application 
activated sludge process for the treatment domestic urban wastewater for reuse treated wastewater in agriculture.

\section{Materials and Methods}

The elimination of harmful substances from waste water requires treatment before discharge. This treatment involves the reduction of the pollution load rejection.

Our laboratory of process separation, to conduct research work in this domain, has a simple purification pilot plant wastewater by activated sludge.

\subsection{Sampling Point}

Samplings are made on domestic effluent from the city of Kenitra. Pollution loads are assumed to be all of domestic origin.

During sampling, the temperature, $\mathrm{pH}$, conductivity, turbidity and dissolved oxygen were measured in the field. All samples were stored at $4^{\circ} \mathrm{C}$ and analyzed in the laboratory within 24 hours that follow. The transport time between the source collection and laboratory never exceeded 2 hours.

\subsection{Period and Sampling Frequency}

Our study was spread over a period of 4 months (March, April, May, and June). The wastewater sampling was done weekly at the outlet of the sanitary sewer network of the city of Kenitra.

The study of the physical and chemical quality is carried out during the whole period because it is strongly recommended to do the campaigns of analyzes in dry weather. In general, the period of the most appropriate study ranges between March and October [4].

\subsection{Quality of the Raw Water}

The measured average parameters are summarized in Table. 1. Pollution loads are assumed to be all of domestic origin.

Table 1. The Quality of raw wastewater.

\begin{tabular}{lll}
\hline Parametres & measures & $\begin{array}{l}\text { Moroccan standards of } \\
\text { wastewater }\end{array}$ \\
\hline Temperature $\left({ }^{\circ} \mathrm{C}\right)$ & 23,1 & $<30$ \\
$\mathrm{pH}$ & 7,8 & $5,5<\mathrm{pH}<9,5$ \\
Turbidity $(\mathrm{NTU})$ & 345 & - \\
$\begin{array}{l}\text { Dissolved oxygen }(\mathrm{mg} / \mathrm{l}) \\
\text { Conductivity }(\mu \mathrm{S} / \mathrm{cm})\end{array}$ & 0,71 & - \\
$\begin{array}{l}\text { Total Suspended solids } \\
\begin{array}{l}\text { (TSS) }(\mathrm{mg} / \mathrm{L}) \\
\text { Volatile Suspended Solids }\end{array}\end{array}$ & 985 & - \\
$\begin{array}{l}\text { (VSS) }(\mathrm{mg} / \mathrm{L}) \\
\begin{array}{l}\text { Biological oxygen demand } \\
(\mathrm{BOD})(\mathrm{mg} / \mathrm{l})\end{array}\end{array}$ & 344,4 & $35<\mathrm{SS}<100$ \\
$\begin{array}{l}\text { Chemical oxygen demand } \\
(\mathrm{COD})(\mathrm{mg} / \mathrm{l})\end{array}$ & 245 & - \\
\hline
\end{tabular}

\subsection{Description of Procedure and Treatment Methods}

Before starting treatment, adequate pre-treatment is necessary. The latter is intended to extract the elements of nature or size which would be an embarrassment for subsequent processes. The treatment process is summarized in Figure. 1.

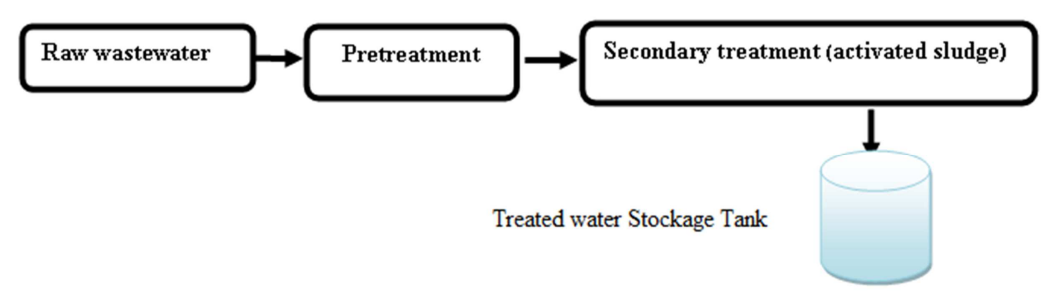

Figure 1. Steps of the suggested treatment.

This sector should allow eliminating most of the carbon pollution. It consists of two main steps: Pretreatment and secondary treatment.

- Pretreatment consists of a physical separation which aims to remove the raw wastewater of the coarsest solid pollutants (screening, grit removal, settling) [5, 6, and 7].

- Secondary treatment selected in our case is the activated sludge.

The activated sludge treatment was performed on a laboratory pilot whose principle and description are given in Figure 2.

The pilot of treatment of wastewater is implemented in the laboratory and it includes an aeration tank fed by a peristaltic pump for sucking raw wastewater from sewage storage tank, and continuous agitation by an electric stirrer. $[5,6,7,8]$

While the diaphragm pump supplies aeration tank by oxygen. we can adjusted this quantity of oxygen by the flow meter. The aeration tank communicates with a final settling tank. The purified water is stored in a tank of treatment water. Activated sludge which is formed is recirculated using a pump to the aeration tank as shown in Figure 2. [5, 6, 7, 8, 10, 11].

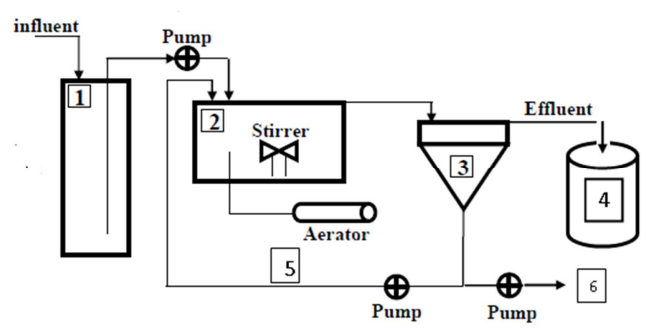

Figure 2. Station pilot of activated sludge.

1. Wastewater storage Tank; 2. Reactor (Aeration tank); 3. Clarificator; 4. Treated water storage Tank; 5. Return Activated Sludge (RAS); 6. Waste Activated Sludge (WAS) 


\subsection{The Operation Forming Activated Sludge}

For launching a biological activated sludge treatment, we must sow the aeration tank by activated sludge. To form sludge, raw wastewater is allowed to circulate in the closed circuit station for a week until the recovery of sufficient sludge, then the jars are emptied and washed, the sludge recovered for subsequent reuse trying to treat biologically.

\section{Results and Discussion}

\subsection{Optimization of Operating Parameters of the Pilot Plant Activated Sludge Treatment}

The purpose of this section is to optimize the operation of activated sludge pilot to set the operating conditions allowing the best results of disposal indicator parameters of pollution. First, the operating parameters of the pilot station (flow of feed and oxygenation rate) were followed and optimized. After that we can start the treatment for eliminating pollution. Throughout the study, the stirring speed of the aeration basin was set at 100 revolutions (rev) / minute (stirring speed) and the rate of recycling of decanted activated sludge into the clarifier to the aeration basin was all the time $100 \%$.

During the study, the conventional parameters of operation of an activated sludge were followed: sludge index, mass loading, volume load, turbidity, suspended matter, hydraulic residence time, $\mathrm{pH}$, conductivity and temperature.

a Optimization of the feed flow

Table 2. Shows the operating conditions for pilot optimization tests of the feed flow.

Table 2. The optimization of operating pilot at different feed flow.

\begin{tabular}{lllll}
\hline influent flow (l/h) Parameters & $\mathbf{0 . 5}$ & $\mathbf{1}$ & $\mathbf{1 . 5}$ & $\mathbf{2}$ \\
\hline Oxygen rate (\%) & 100 & 100 & 100 & 100 \\
Stiring velocity (ver/min) & 100 & 100 & 100 & 100 \\
Recirculation of the activated sludge (\%) & 100 & 100 & 100 & 100 \\
\hline
\end{tabular}

Table 3. Gives the variations of operating parameters as a function of the feed flow of the aeration basin; the variations of these changes are shown in Figures $3,4 \& 5$.

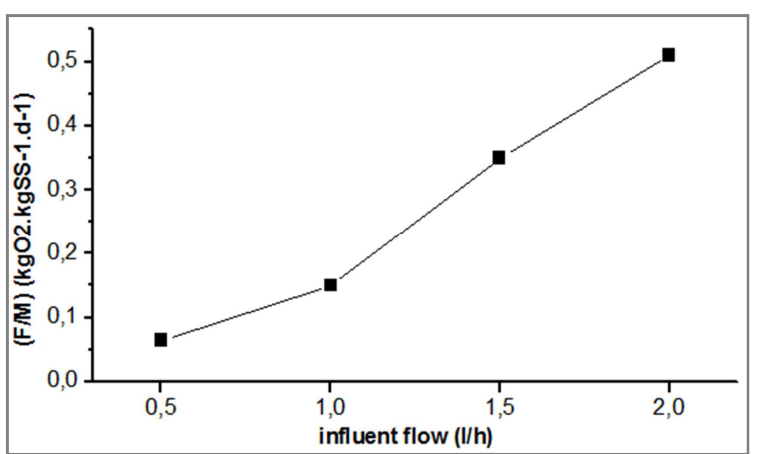

Figure 3. Variation of $F / M$ as a function of feed flow.

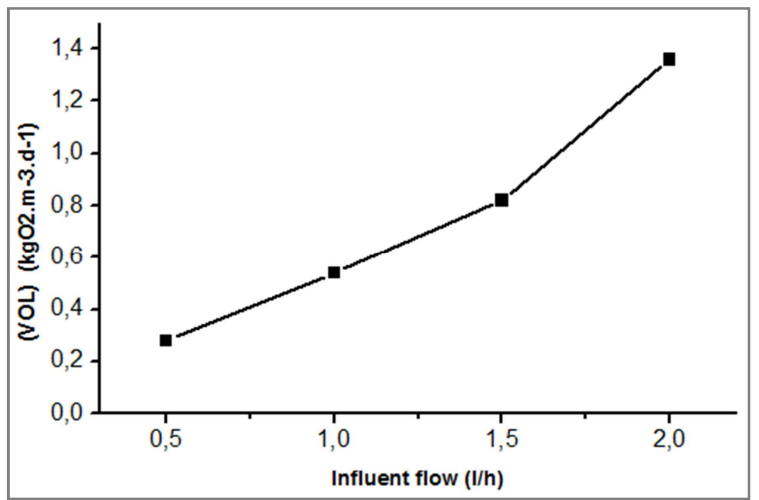

Figure 4. Variation of VOL as a function of feed flow.

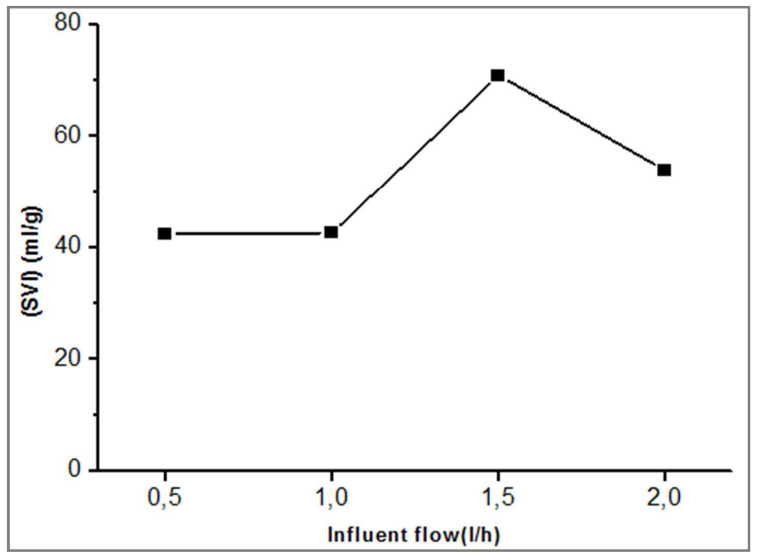

Figure 5. Variation of SVI as a function of feed flow.

Table 3. Variation as a function of the feed flow of the operating parameters of the aeration basin.

\begin{tabular}{|c|c|c|c|c|}
\hline & Aeration Tank & & & \\
\hline Days and influent flow $(\mathrm{l} / \mathrm{h})$ parameters & $1^{\text {st }}$ Day $0,5 \mathrm{l} / \mathrm{h}$ & $2^{\text {nd }}$ Day $11 / h$ & $3^{\text {th }}$ Day $1,5 \mathrm{l} / \mathrm{h}$ & $4^{\text {th }}$ Day $21 / h$ \\
\hline Temperature $\left({ }^{\circ} \mathrm{C}\right)$ & 20,7 & 20,3 & 20,8 & 21 \\
\hline $\mathrm{pH}$ & 8,15 & 8,12 & 8,44 & 8,20 \\
\hline Turbidity (NTU) & 987 & 811 & 750 & 607 \\
\hline Dissolved oxygen (mg/l) & 6,54 & 5,47 & 5,17 & 4,20 \\
\hline Conductivity $(\mu \mathrm{S} / \mathrm{cm})$ & 897 & 998 & 893 & 890 \\
\hline Total Suspended solids (SS) (mg/L) & 5428,5 & 4460,5 & 2925,5 & 3338,5 \\
\hline Volatile Suspended Solids (VSS)(mg/L) & 4342,8 & 3568,4 & 2340,4 & 2670,8 \\
\hline Food to Microorganism Ratio $(\mathrm{F} / \mathrm{M})\left(\mathrm{kgBOD}_{5} \cdot \mathrm{kgMLVSS}^{-1} \cdot \mathrm{d}^{-1}\right)$ & 0,064 & 0,15 & 0,35 & 0,51 \\
\hline Volumetric organic loading $(\mathrm{VOL})\left(\mathrm{kg} \mathrm{BOD} \cdot \mathrm{m}^{-3} \cdot \mathrm{d}^{-1}\right)$ & 0,28 & 0,54 & 0,82 & 1,36 \\
\hline Hydraulic detention time (h) & 17 & 8.5 & 5,66 & 4,25 \\
\hline Sludge Volume Index (SVI) (ml/g) & 42,37 & 42,60 & 70,84 & 53,92 \\
\hline
\end{tabular}


Table 4. Influence of feed flow on purification performance.

\begin{tabular}{|c|c|c|c|c|c|c|c|c|c|}
\hline \multirow[b]{2}{*}{$\begin{array}{l}\text { Days and influent flow } \\
\text { (1/h) parametres }\end{array}$} & \multirow[t]{2}{*}{$\begin{array}{l}\text { raw } \\
\text { wastewater }\end{array}$} & \multicolumn{8}{|c|}{ Treated water } \\
\hline & & $1^{\text {st }} 0,5 \mathrm{l} / \mathrm{h}$ & $\begin{array}{l}\%) \\
\text { Removal (R) } \\
\end{array}$ & $2^{\text {nd }} 1 \mathrm{l} / \mathrm{h}$ & $\begin{array}{l}(\%) \\
\text { Removal (R) }\end{array}$ & $\begin{array}{l}3^{\text {th }} 1,5 \\
1 / h\end{array}$ & $\begin{array}{l}\text { (\%) Removal } \\
\text { (R) }\end{array}$ & $4^{\text {th }} 2 \mathrm{l} / \mathrm{h}$ & $\begin{array}{l}\text { (\%) Removal } \\
\text { (R) }\end{array}$ \\
\hline Temperature $\left({ }^{\circ} \mathrm{C}\right)$ & 23,1 & 20,6 & -- & 19,9 & -- & 20,5 & -- & 20,6 & -- \\
\hline $\mathrm{pH}$ & 7,8 & 8,12 & -- & 8,07 & -- & 8,4 & -- & 8,34 & -- \\
\hline Turbidity (NTU) & 345 & 5 & 98,55 & 8 & 97,68 & 12 & 96,52 & 10,90 & 96,84 \\
\hline Dissolved oxygen (mg/l) & 0,71 & 5,24 & -- & 4,20 & -- & 4,50 & -- & 4,73 & -- \\
\hline Conductivity $(\mu \mathrm{S} / \mathrm{cm})$ & 926 & 920 & -- & 950 & -- & 925 & -- & 911 & -- \\
\hline $\begin{array}{l}\text { Total Suspended solids (SS) } \\
(\mathrm{mg} / \mathrm{L})\end{array}$ & 430,5 & 15 & 96,51 & 20 & 95,35 & 25 & 94,19 & 26 & 93,96 \\
\hline $\begin{array}{l}\text { Volatile Suspended Solids } \\
\text { (VSS)(mg/L) }\end{array}$ & 344,4 & 12 & -- & 16 & -- & 20 & -- & 20,8 & -- \\
\hline $\begin{array}{l}\text { Biological oxygen demand } \\
\left(\mathrm{BOD}_{5}\right)(\mathrm{mg} / \mathrm{l})\end{array}$ & 245 & 25 & 89,79 & 60 & 75,51 & 75 & 69,38 & 90 & 63,26 \\
\hline $\begin{array}{l}\text { Chemical oxygen demand } \\
\text { (COD) }(\mathrm{mg} / \mathrm{l})\end{array}$ & 480 & 45 & 90,62 & 100 & 79,16 & 130 & 72,91 & 185 & 61,45 \\
\hline
\end{tabular}

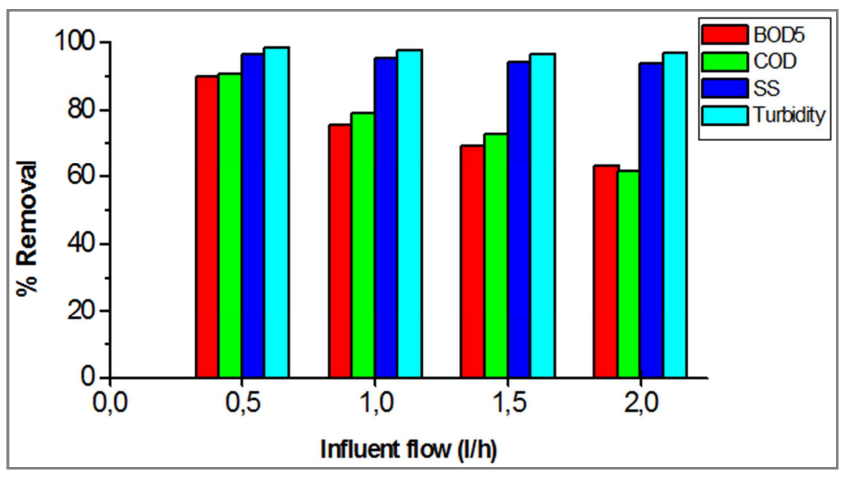

Figure 6. Reduction of pollution parameters as a function the feed flow.

The decrease in feed flow resulted in a decrease in the mass load and volume load. The pilot station for the mass loading of a high load to a low load and even at prolonged aeration as regards the slowest circulation rate. While the operation of treatment is taking place, the mass loading varies of a high load to a low load and even at prolonged aeration as regards the slowest circulation rate. This result is translated by an amelioration of the performance wastewater treatment plant by moving from high speed to low speed circulation rate (debit).

Changes in the index of sludge are generally going in the same direction as the mass load. However, the index of sludge is excellent for all speed circulation rate indicating good settling sludge.

The table. 4. and figures. 3. \& 6 show that the performance of the pilot station ameliorate by going from the high load to the low load average. Indeed, the reduction in flow resulted in improved treatment rates of different monitored parameters.
These results also show that the rate of reduction of turbidity and suspended matter are significantly better than those of $\mathrm{COD}$, and $\mathrm{BOD}_{5}$. The reduction rate of suspended matter and turbidity exceed the $95 \%$ to $99 \%$ for the lower mass load. For high flow rates, so high specific load, the reduction rate of $\mathrm{COD}$ and $\mathrm{BOD}_{5}$ remain low and below normal reduction rate of an activated sludge at high load.

European emission standards are achieved with the lowest velocity to $0.5 \mathrm{l} / \mathrm{h}$. So the pilot works in the lower mass and volume loads.

It is important to note that the sludge was not renewed during the whole step of optimizing the speed of circulation. The sludge age was followed and experimentally determined in the order of 11 days.

\section{$b$ Optimization of the oxygenation rate}

The optimization of the oxygenation rate was achieved at the lowest debit $(0,5 \mathrm{l} / \mathrm{h})$ which gives the lowest mass loading. The table. 5. Shows the operating conditions of the pilot in the optimization tests of the oxygenation rate.

Table 5. Optimization of the operating conditions of the pilot plant at various oxygenation rates.

\begin{tabular}{lllll}
\hline Oxygen rate (\%) Parameters & 100 & 80 & 40 & 20 \\
influent flow $(\mathrm{l} / \mathrm{h})$ & 0.5 & 0.5 & 0.5 & 0.5 \\
Stiring velocity (ver/min) & 100 & 100 & 100 & 100 \\
Recirculation of the activated sludge (\%) & 100 & 100 & 100 & 100 \\
\hline
\end{tabular}

Table. 6. and Figures 7. $8 \& 9$. Give the variations of the operating parameters of the aeration tank as a function of the oxygenation rate.

Table. 7. Shows the changes in physical and chemical parameters of treated wastewater in terms of feed flows $\left(\mathrm{BOD}_{5}, \mathrm{COD}\right.$ and suspended matter). These variations are shown in figure. 10.

Table 6. Variations in the aeration tank operating parameters as a function of the oxygenation rate.

\begin{tabular}{|c|c|c|c|c|}
\hline & Aeration & & & \\
\hline Days and Oxygen rate (\%)parameters & $1^{\text {st }} 100 \%$ & $2^{\text {nd }} 80 \%$ & $3^{\text {th }} 60 \%$ & $4^{\text {th }} 40 \%$ \\
\hline Temperature $(\mathrm{T})\left({ }^{\circ} \mathrm{C}\right)$ & 20,3 & 21,2 & 21,8 & 21 \\
\hline $\mathrm{pH}$ & 8,12 & 8,63 & 7,93 & 8,23 \\
\hline Turbidity (NTU) & 811 & 607 & 466 & 216 \\
\hline Dissolved oxygen $(\mathrm{mg} / \mathrm{L})$ & 5,74 & 5,50 & 3,75 & 3,45 \\
\hline
\end{tabular}




\begin{tabular}{|c|c|c|c|c|}
\hline \multirow[b]{2}{*}{ Days and Oxygen rate (\%)parameters } & \multicolumn{4}{|c|}{ Aeration Tank } \\
\hline & $1^{\text {st }} 100 \%$ & $2^{\text {nd }} 80 \%$ & $3^{\text {th }} 60 \%$ & $4^{\text {th }} 40 \%$ \\
\hline Conductivity $(\mu \mathrm{S} / \mathrm{cm})$ & 998 & 938 & 966 & 943 \\
\hline Mixed liquor suspended solids (MLSS) (mg/l) & 4460,5 & 3338,5 & 2563 & 1188 \\
\hline Mixed liquor volatile Suspended Solids (MLVSS) (mg/L) & 3568,4 & 2670,8 & 2050,4 & 950,4 \\
\hline Food to Microorganism Ratio $(\mathrm{F} / \mathrm{M})\left(\mathrm{kgBOD}_{5} \cdot \mathrm{kgMLVSS}^{-1} \cdot \mathrm{d}^{-1}\right)$ & 0,096 & 0,12 & 0,16 & 0,36 \\
\hline Volumetric organic loading $(\mathrm{VOL})\left(\mathrm{kg} \mathrm{BOD}_{5} \cdot \mathrm{m}^{-3} \cdot \mathrm{d}^{-1}\right)$ & 0,34 & 0,32 & 0,32 & 0,34 \\
\hline Hydraulic detention time (HDT) $(\mathrm{H})$ & 17 & 17 & 17 & 17 \\
\hline Sludge Volume Index (SVI) (ml/g) & 42,80 & 45,3 & 43,11 & 50,20 \\
\hline
\end{tabular}

Table 7. The influence of oxygenation rate on purification performance.

\begin{tabular}{|c|c|c|c|c|c|c|c|c|c|}
\hline & raw wastewater & Treated wat & & & & & & & \\
\hline $\begin{array}{l}\text { Days and Oxygen rate }(\%) \\
\text { parameters }\end{array}$ & & $1^{\text {st }} 100(\%)$ & $(\%) R$ & $2^{\text {nd }} 80 \%$ & (\%) R & $3^{\text {th }} 60 \%$ & (\%) R & $4^{\text {th }} 40 \%$ & (\%) $R$ \\
\hline Temperature $\left({ }^{\circ} \mathrm{C}\right)$ & 23,1 & 20,6 & -- & 21,3 & -- & 21,5 & -- & 21,4 & -- \\
\hline $\mathrm{pH}$ & 7,8 & 8,12 & -- & 8,44 & & 8,6 & & 8,1 & \\
\hline Turbidity (NTU) & 345 & 6 & 98,26 & 5,75 & 98,33 & 7 & 97,97 & 9 & 97,39 \\
\hline Dissolved oxygen (mg/l) & 0,71 & 5,24 & -- & 4,34 & & 4,12 & & 3,85 & \\
\hline Conductivity $(\mu \mathrm{S} / \mathrm{cm})$ & 985 & 802 & -- & 938 & -- & 960 & -- & 957 & -- \\
\hline $\begin{array}{l}\text { Total suspended solids (SS) } \\
(\mathrm{mg} / \mathrm{L})\end{array}$ & 430,5 & 13 & 96,98 & 10 & 97,67 & 18 & 95,81 & 20 & 95,35 \\
\hline $\begin{array}{l}\text { Volatile Suspended Solids } \\
\text { (VSS) }(\mathrm{mg} / \mathrm{L})\end{array}$ & 344,4 & 10,4 & -- & 8 & -- & 14,4 & -- & 16 & -- \\
\hline $\begin{array}{l}\text { Biological oxygen demand } \\
\left(\mathrm{BOD}_{5}\right)(\mathrm{mg} / \mathrm{l})\end{array}$ & 245 & 25 & 89,79 & 18 & 92,65 & 28 & 88,57 & 30 & 87,75 \\
\hline $\begin{array}{l}\text { Chemical oxygen demand } \\
\text { (COD) }(\mathrm{mg} / \mathrm{l})\end{array}$ & 480 & 48 & 90 & 32 & 93,33 & 45 & 90,62 & 63 & 86,87 \\
\hline
\end{tabular}

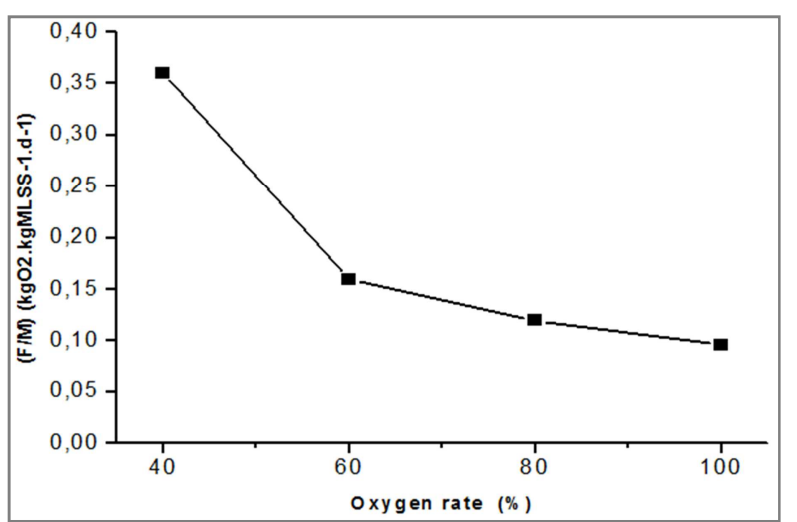

Figure 7. Variations in $F / M$ as a function of oxygen rate.

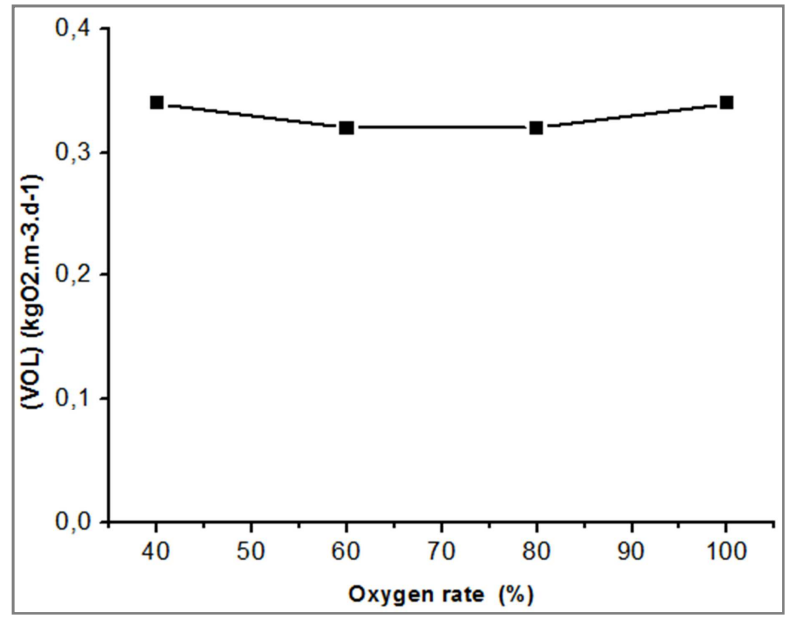

Figure 8. Variations in VOL as a function of oxygen rate.

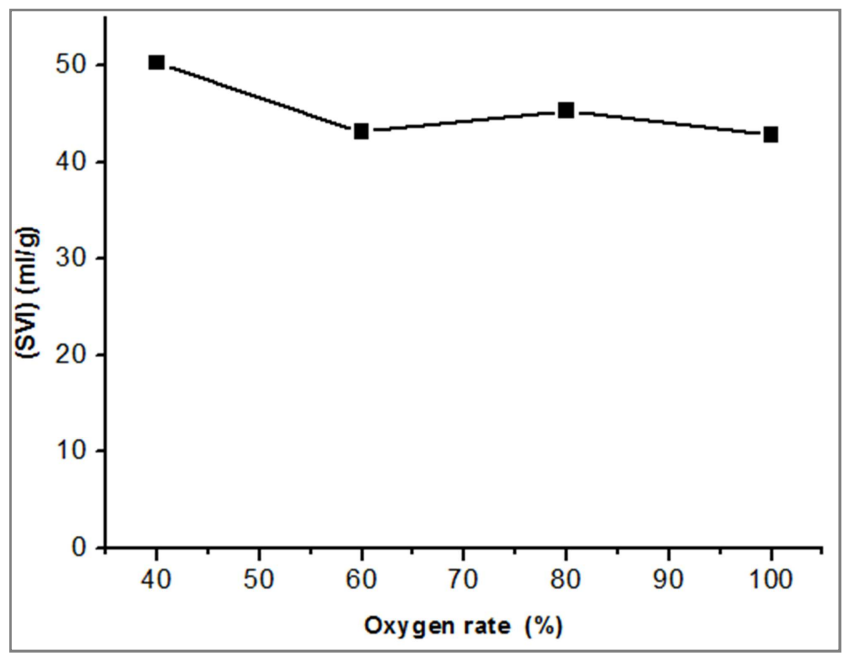

Figure 9. Variation of SVI as a function of oxygen rate.

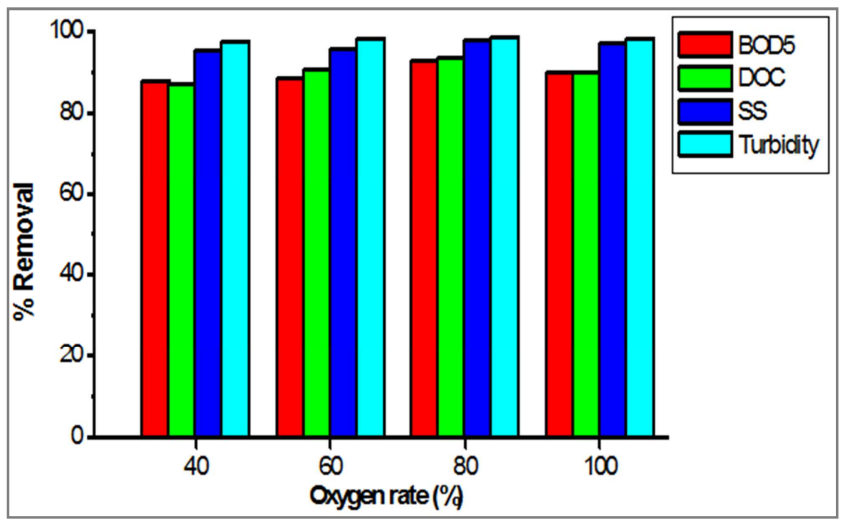

Figure 10. Reduction of pollution parameters as a function of oxygen rate. 
Table.6. and Figures 7, $8 \& 9$ shows that the decrease of the oxygenation rate has no significant influence on the volume load. However, it had an effect on the mass load. All the results of the table and the figures show a slight influence of the variation of the oxygenation rate on the performance of this station and in the oxygenation range studied. The pilote works in the range of parameters imposed as a low load. The reductions of $\mathrm{BOD}_{5}$ and $\mathrm{COD}$ are higher than $88 \%$. Those of the Suspended matter and turbidity exceed 98\% (figure 10).

European emission standards are met for various oxygenation rates.

The quality of the water produced is greatly better than that imposed by the Moroccan standards. The sludge age measured in this case was 14 days.

\subsection{Trials Treating Wastewater by Optimized Parameters}

In order to confirm the performance of the station, a long duration of the pilot purification test was conducted. The pilot operating conditions correspond in terms of mass load to a low load are: Flow $0.51 / \mathrm{h}$; Oxygenation rate $60 \% ; 100 \%$ recycling of the activated sludge; Aeration tank agitation 100 $\mathrm{rev} / \mathrm{min}$.

The following table. 8. shows the performance of the wastewater treatment station for five days of continuous operation. The variations of these performances are given in Figure 11.

Table 8. Percentage of the reduction of physicochemical parameters (pollution) of treated wastewater by activated sludge after optimized parameters the functional pilot station.

\begin{tabular}{|c|c|c|c|c|c|c|c|c|c|c|c|}
\hline \multirow[b]{2}{*}{ Days parametres } & \multirow[t]{2}{*}{ raw wastewater } & \multicolumn{10}{|c|}{ Treated water } \\
\hline & & $\mathbf{1}^{\text {st }}$ day & (\%) R & $2^{\text {nd }}$ day & $(\%) R$ & $3^{\text {th }}$ day & $(\%) \mathrm{R}$ & $4^{\text {th }}$ day & $(\%) R$ & $5^{\text {th }}$ day & $(\%) R$ \\
\hline Temperature $\left({ }^{\circ} \mathrm{C}\right)$ & 23,1 & 23,3 & -- & 23,00 & -- & 23,9 & -- & 23,7 & -- & 23,4 & -- \\
\hline $\mathrm{pH}$ & 7,8 & 8,03 & -- & 7,85 & -- & 8,1 & -- & 7,93 & -- & 8,00 & -- \\
\hline Turbidity (NTU) & 345 & 6 & 98,26 & 5 & 98,55 & 4,45 & 98,71 & 5,47 & 98,41 & 6,50 & 98,11 \\
\hline Dissolved oxygen $(\mathrm{mg} / \mathrm{l})$ & 0,71 & 3,90 & -- & 3,47 & -- & 4,04 & -- & 3,90 & -- & 3,53 & -- \\
\hline Conductivity $(\mu \mathrm{S} / \mathrm{cm})$ & 985 & 956 & -- & 958 & -- & 986 & -- & 990 & -- & 985 & -- \\
\hline $\begin{array}{l}\text { Total suspended solids } \\
\text { (SS) }(\mathrm{mg} / \mathrm{L})\end{array}$ & 430,5 & 10 & 97,67 & 13 & 96,98 & 12 & 97,21 & 11 & 97,44 & 14 & 96,74 \\
\hline $\begin{array}{l}\text { Volatile Suspended } \\
\text { Solids (VSS)(mg/L) }\end{array}$ & 344,4 & 8 & -- & 10,4 & --- & 9,6 & -- & 8,8 & -- & 11,2 & -- \\
\hline $\begin{array}{l}\text { Biological oxygen } \\
\text { demand }\left(\mathrm{BOD}_{5}\right)(\mathrm{mg} / \mathrm{l})\end{array}$ & 245 & 25 & 89,79 & 30 & 87,75 & 24 & 90,20 & 32 & 86,93 & 30 & 87,75 \\
\hline $\begin{array}{l}\text { Chemical oxygen } \\
\text { demand (COD) }(\mathrm{mg} / \mathrm{l})\end{array}$ & 480 & 60 & 87,5 & 68 & 85,83 & 49 & 89,79 & 68 & 85,83 & 72 & 85 \\
\hline
\end{tabular}

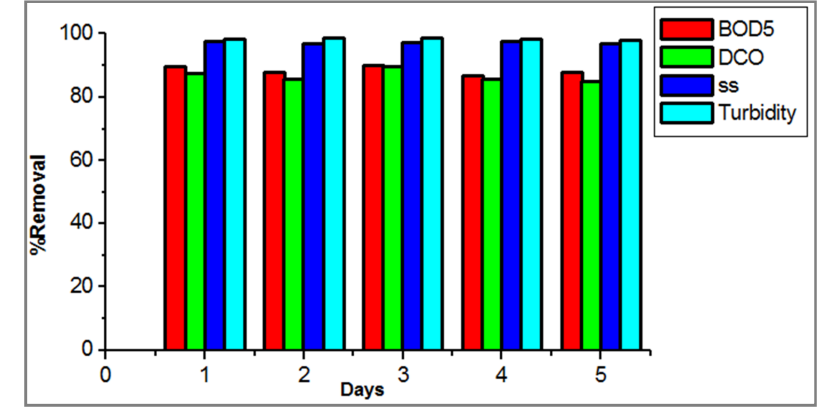

Figure 11. Reduction of pollution parameters as a function of the day after optimized parameters.

These results confirm the higher performance of the station in the purification of wastewater of Kenitra. These results also show the consistency of the performance for five consecutive days, during which, the station operated in low mass loading, and a flow rate of $0.5 \mathrm{l} / \mathrm{h}$ and a $60 \%$ oxygen, producing water with much lower levels in European and Moroccan discharge standards.

\section{Conclusion}

The results of this study showed a reduction of pollution load $\mathrm{BOD}_{5}$, COD and suspended matter which is respectively $(90.20 \%, 89.79 \%$ and $97.67 \%)$ and an improved quality of treated water. These results confirm the good performance of the station in the purification of wastewater in Kenitra. Also, a sustained performance during the trial period, during which, the station operated in low mass load, producing water with much lower levels in European and Moroccan discharge standards. The final treated wastewater could be reused water for agricultural irrigation after disinfection.

\section{References}

[1] N. Ben Amar, N. Kechaouc, John Palmerid, A. Deratani, A. Sghaier, Comparison of tertiary treatment by nanofiltration and reverse osmosis for water reuse in denim textile industry, Journal of Hazardous Materials 170 (2009) 111-117.

[2] D. Bolzonella, F. Fatone, S. di Fabio, F. Cecchi, Application of membrane bioreactor technology for wastewater treatment and reuse in the Mediterranean region: Focusing on removal efficiency of non-conventional pollutants, Journal of Environmental Management 91 (2010) 2424-2431.

[3] A. Ziyad, water resource management in Morocco: balance and perspectives, HTE News No. 142 • March-June 2009.

[4] Ministry of Energy, Mines, Water and Environment, Department of Water, Water Policy in Morocco in September 2012, flap.

[5] Office National of Electricity and Drinking Water (ONEE), Rabat, Morocco (1999). 
[6] M. A. Fulazzaky, journal of engineering science and technology, carbonaceous, nitrogenous and phosphorus matters removal from domestic wastewater by an activated sludge reactor of nitrification-denitrification type, vol. 4, no. 1 (2009) 69-80.

[7] S. Clesceri., L. Eaton, D. Andrew, and E. A. Greenberg, Standard Methods for the Examination of Water and Wastewater (19th edition); American Public Health Association, American Water Works Association and Water Environment Federation, 1995.

[8] R. L. Droste., Theory and Practice of Water and Wastewater Treatment, John Wiley \& Sons, 1997, New York, pp. 219-242.
[9] W. W. Eckenfelder, Industrial Water Pollution Control, Mcgraw-Hill, New York, 1989, pp. 33-39.

[10] M. D. lagrega., P. L. Buckingham., J. C. Evans., Hazardous Waste Management, mcgraw-Hill, 1994, New York, pp. 405444.

[11] Metcalf \& Eddy, Wastewater Engineering: Treatment, Disposal, And Reuse, mcgraw-Hill, 1991, New York, pp. 121146.

[12] D. W. Sundstrom, And H. E. Klei, Wastewater Treatment, Prentice Hall, Englewood Cliffs, 1979, NJ, pp. 28-40. 